See Article page 179

\section{Commentary: Changing times, changing faces}

\author{
Maral Ouzounian, MD, PhD, FRCSC, \\ Jennifer C.-Y. Chung, MD, MSc, FRCSC, and \\ Vivek Rao, MD, PhD, FRCSC
}

Our community is changing. Increasing attention has been given to the lack of female representation in cardiothoracic surgery. As with other surgical subspecialties, there are an increasing number of female trainees, although among faculty cardiac surgeons in North America, less than $10 \%$ are women. $^{1,2}$ As we go up the clinical echelon, the numbers become abysmally low, with very few female division or department chairs. ${ }^{3,4}$ In the academic sphere, the ratios are worse, with poor female representation among full professors, editorial boards of our journals, principal investigators of clinical trials, and leadership positions in our surgical societies. ${ }^{5-10}$ A similar landscape is evident when we review the proportion of underrepresented minorities in our community, particularly when we consider the intersectionality of sex, race, and other aspects of social identity.

Gemmato and Baldwin's experiences in this issue of the Journal highlight some of the challenges faced by young surgeons navigating training in cardiothoracic surgery while starting a family. ${ }^{11}$ They describe the implicit bias and microaggressions familiar to many in the workplace and offer suggestions to both men and women seeking to balance a fulfilling career with a life outside the hospital.

In our cardiac surgery division at the Toronto General Hospital, University of Toronto, we have 2 female cardiac surgeons (M.O. and J.C.) who specialize in aortic surgery. In addition to reviewing complex cases, having a team approach to aortic emergencies and thoracoabdominal aneurysms, we have been able to support each other through maternity leaves while

\footnotetext{
From the Division of Cardiovascular Surgery, Peter Munk Cardiac Centre, Toronto General Hospital, University of Toronto, Toronto, Ontario, Canada.

Disclosures: Dr Ouzounian reported consulting agreements with Medtronic Inc and CryoLife. Dr Rao reported consulting agreements with Medtronic Inc, Abbott, and Gore Medical. Dr Chung reported no conflicts of interest.

The Journal policy requires editors and reviewers to disclose conflicts of interest and to decline handling or reviewing manuscripts for which they may have a conflict of interest. The editors and reviewers of this article have no conflicts of interest.

Received for publication Nov 2, 2020; revisions received Nov 2, 2020; accepted for publication Nov 3, 2020; available ahead of print Nov 6, 2020.

Address for reprints: Maral Ouzounian, MD, PhD, FRCSC, Division of Cardiac Surgery Toronto General Hospital, 200 Elizabeth St 4N-464, Toronto, Ontario M5G2C4, Canada (E-mail: Maral.ouzounian@uhn.ca).

J Thorac Cardiovasc Surg 2022;163:187-8

$0022-5223 / \$ 36.00$

Copyright (c) 2020 by The American Association for Thoracic Surgery

https://doi.org/10.1016/j.jtcvs.2020.11.013
}

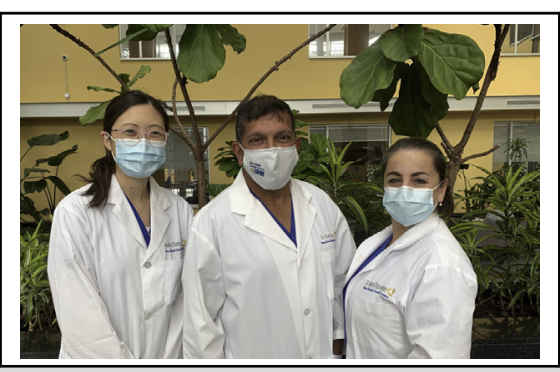

(Left to right): Jennifer C.-Y. Chung, MD, MSc FRCSC, Vivek Rao, MD, PhD, FRCSC, and Maral Ouzounian, MD, PhD, FRCSC

\section{CENTRAL MESSAGE}

The cardiothoracic surgery community must embrace the call to increase diversity in our specialty.

building our aortic practices and academic careers. We have found relief from the burden of being the *only* female voice in the division, no longer having to represent $50 \%$ of the population with our individual views. Having more than one female cardiac surgeon within the division has instantly "normalized" what was once considered to be an uncommon position. A third female cardiac surgeon is slated to start in July 2021, undoubtedly a rare assembly in any cardiac center. In addition, 4 of 9 surgeons in our division are underrepresented minorities. Although none of us were hired because of our race or gender, having a diverse division strengthens our group, reflects our larger community, and provides better access for medical students, residents, and fellows seeking mentorship.

Awareness of these issues is increasing, and the tide is changing. The year 2020 saw the election of Dr Yolonda Colson as the first female officer of the American Association for Thoracic Surgery at its 100th Annual Scientific meeting. ${ }^{12}$ Our current American Association for Thoracic Surgery president, Dr Marc Moon, has put forth a call for action to our community: "Diversity in academic medicine does not occur passively, it requires a concerted effort to change the face of cardiothoracic surgery, both active and continuous." We are proud that our division embraces diversity, while simultaneously achieving clinical and academic excellence. We urge our colleagues, institutions, and professional societies to embrace the call of Dr Moon to change the faces of cardiothoracic surgery through mentorship and sponsorship of the next generation. We will no doubt all be better for it. 


\section{References}

1. Stephens EH, Robich MP, Walters DM, DeNino WF, Aftab M, Tchantchaleishvili V, et al. Gender and cardiothoracic surgery training: specialty interests, satisfaction, and career pathways. Ann Thorac Surg. 2016; 102:200-6.

2. Ikonomidis JS, Boden N, Atluri P. The Society of Thoracic Surgeons thoracic surgery practice and access task force-2019 workforce report. Ann Thorac Surg. 2020;110:1082-90.

3. Jagsi R, Means O, Lautenberger D, Jones RD, Griffith KA, Flotte TR, et al. Women's representation among members and leaders of national medical specialty societies. Acad Med. 2020;95:1043-9.

4. Pories SE, Turner PL, Greenburg CC, Babu MA, Parangi S. Leadership in American surgery women are rising to the top. Ann Surg. 2019;269:199-205.

5. Carr PL, Raj A, Kaplan SE, Terrin N, Breeze JL, Freund KM. Gender differences in academic medicine: retention, rank, and leadership comparisons from the $\mathrm{Na}$ tional Faculty Survey. Acad Med. 2018;93:1694-9.

6. Narahari AK, Cook IO, Mehaffey JH, Chandrabhatla AS, Hawkins RB, Tyerman Z, et al. Comprehensive National Institutes of Health funding analysis of academic cardiac surgeons. J Thorac Cardiovasc Surg. 2020; 159:2326-35.e3.

7. Luc JGY, Vervoort D, Percy E, Hirji S, Mann GK, Phan K, et al. Trends in female authorship: a bibliometric analysis of the Annals of Thoracic Surgery. Ann Thorac Surg. August 19, 2020 [Epub ahead of print].

8. Olive JK, Preventza OA, Blackmon SH, Antonoff MB. Representation of women in the Society of Thoracic Surgeons authorship and leadership positions. Ann Thorac Surg. 2020;109:1598-604.

9. Jena AB, Khullar D, Ho O, Olenski AR, Blumenthal DM. Sex differences in academic rank in US medical schools in 2014. JAMA. 2015;314:1149.

10. Whitelaw S, Thabane L, Mamas MA, Reza N, Breathett K, Douglas PS, et al. Characteristics of heart failure trials associated with under-representation of women as lead authors. J Am Coll Cardiol. 2020;76:1919-30.

11. Gemmato CJ, Baldwin ACW. Yes, we are both cardiac surgeons: one family's unique perspective on work-life balance. J Thorac Cardiovasc Surg. 2022;163: 179-83.

12. Lawton JS. A historic event: the first female officer of the American Association for Thoracic Surgery. J Thorac Cardiovasc Surg. July 4, 2020 [Epub ahead of print]. 